\title{
Use of Action Songs and Total Physical Response to Promote the Development of Listening Skills among Year 4, Low Enrolment-Tamil Vernacular Primary School Students in Malaysia
}

\author{
Uthaya Kumar, S. \& Sandaran, S. C. \\ Language Academy, Faculty of Social Science and Humanities, Universiti Teknologi Malaysia, 81310 UTM \\ Johor Bahru, Johor, Malaysia
}

Submitted: 25/11/2018. Revised edition: 9/12/2018. Accepted: 18/12/2018. Published online: 18/12/2018

\begin{abstract}
Total Physical Response (TPR) is built around the coordination of speech and actions. Action songs promote dance or acts while singing. In this study, we look at action songs as part of TPR to investigate its effectiveness in enhancing students' listening skills to develop their mastery of the English Language. Seven Year 4 students from a Low Enrolment (SKM) Tamil Vernacular Primary school type (SJKT) were selected as the participants of a within-group experimental design. Upon completing a pre-test on listening skill, students were given six treatment lessons, whereby one hour per lesson was allocated. The treatment was conducted once a week, for every listening lesson. The data was collected while and after the pupils were taught through a series of lessons or interventions that incorporated songs and TPR to complete a variety of listening tasks. The finding shows that even though action songs and TPR are not commonly used among English Language teachers, teachers should implement the method especially for students from Low Enrolment Vernacular Primary School Type as the students in this study showed a significant increase in their post intervention scores of the listening test. The findings also discusses SJKT English Language teachers perceptions on the use of songs and TPR and suggests that there is still a lack of understanding among the teachers on the potential benefits of action songs and TPR for their particular students who have high levels of anxiety and inhibitions to learning English.
\end{abstract}

Keywords: Listening skill, KSSR, Total Physical Response, Action Songs, Low Enrolment Schools (SKM), Tamil Vernacular Primary School (SJKT)

\subsection{INTRODUCTION}

The teaching of the listening skill has always been regarded as least important among the four language skills. As Alderson, Brunfaut, \& Harding (2015) state, listening is a skill that is often forgotten when it comes to language teaching. However, listening is said to be the most important of the four language skills as young children imitate to produce the language and this imitation occurs through the process of listening and acquiring of the sounds first (Harding \& Brunmfaut, ibid).

\footnotetext{
*Correspondence to: Sandaran, S. C. (email: shanti@utm.my)
} 
Recognizing the importance of listening, the Malaysian English Language Curriculum for Primary Schools (Kurikulum Standard Sekolah Rendah, KSSR), has placed more emphasis on the teaching of listening especially for early literacy, in the initial stages of young children's learning of the English Language. In addition to the focus on the teaching of listening, the KSSR further emphasizes on learning to be made fun and meaningful via the incorporation of multiple intelligences which takes into consideration young learners' different intelligences, learning styles, and needs.

One sure way of teaching listening that embodies the principles of multiple intelligences and different learning styles, which also makes learning fun and meaningful, is the use of songs in the classroom. Songs are one of the most pleasurable techniques to practice and progress in listening skills (Sevik, 2012). The use of songs has also been suggested in the Standard Curriculum and Assessment Document (2015) for KSSR. When songs are integrated into language teaching, some of the elements of multiple intelligences such as bodily-kinesthetic, musical and linguistic elements are present. The use of songs for the teaching of the listening is based on music that is associated with language learning. Music contains authentic and informal language that is natural to the ear (Sigurðardóttir, 2012). According to Alisaari (2015), singing can be useful for receptively learning structures, which makes it ideal for listening, as listening is a receptive skill. When children listen to new vocabulary through songs, there is a greater chance of retention of the words from the songs. Songs also enable them to learn new vocabulary in a fun manner. As Sevik (2012) attests, songs can be one of the most enjoyable ways to practice and develop listening skills. A further expansion of using songs which the current study draws on for the teaching of listening is the inclusion of physical movements such as reaching, moving or touching. This is known as Total Physical Response (TPR), an approach for teaching that is built around the coordination of speech and action and a focus on teaching languages through physical movements (Mustafa Sevik, 2012). TPR is based on the view that when acquiring their first language, children do a lot of listening, before they speak, and that their listening is followed by physical movement. Thus including motions that parallel the words of the song makes the songs more expressive and fun (Saricoban and Metin in Sevik, 2012).

In-line with KSSR's blueprint that promotes the teaching of listening through songs, making learning fun and meaningful, and incorporating multiple intelligences, this paper draws upon previous studies that have investigated the teaching of listening to young learners (e.g. Change, 2009; Hugo \& Horn, 2013; Rogers, 2012) and especially those that have focused on action songs (e.g. Porvaldsdottir, 2008; Millington, 2011; Sevik, 2012; Tse, 2015) and Total Physical Response (Brown, 2007). It reports on the findings of our investigation of the use of 'action songs' and total physical response to enhance the teaching and learning of listening to young learners, i.e. Year 4 students (aged 10) from a Tamil Vernacular Primary School (Sekolah Jenis Kebangsaan Tamil, SJKT), which is also a LowEnrolment School (Sekolah Kurang Murid). To the knowledge of the researchers, while the teaching of listening in Second Language is widely researched, there is still a need for more investigation within the context of Malaysian schools and especially English Language Teaching practices in lowenrolment Tamil Vernacular Primary Schools as most studies have looked at for example, the school culture (e.g. Selvaraja \& Zaidatol Akmaliah Lope Pihie, 2015) and the status of Tamil Language in Malaysia (e.g. Normadhiah Ibrahim, 2018). 


\subsection{LITERATURE REVIEW}

\subsection{KSSR and the Teaching of English in a Low Enrolment Tamil Vernacular Primary School Type}

In this section, we discuss some of the key aspects for the context of the current study, namely, KSSR, Tamil Vernacular Primary School Type and Low Enrolment Schools.

\section{- Kurikulum Standard Sekolah Rendah (KSSR)}

The Malaysian English Language teaching and learning scenario has seen many changes over the years. One such change was the introduction of the new Malaysian English Language Curriculum for Primary Schools (Kurikulum Standard Sekolah Rendah, KSSR) in 2011. As stated in the KSSR blueprint, English is taught as a second language in all Malaysian Primary and secondary schools and thus, mastery of English is the main focus. KSSR states that the English language should play an important role in fulfilling the physical, emotional, spiritual, intellectual, and social needs of learners, and thus, mastering of the language skills is crucial to prepare them to make accurate and systematic language choices in social interaction (Tajularipin Sulaiman et al., 2015). KSSR also focuses on listening as it states that listening and speaking are looked at as the main skills of early literacy in the initial stages of learning English and that students should have the chance to listen to meaningful input from different sources (Curriculum Development Division, 2015). KSSR thus, calls for an improved quality of the teaching and learning process. In addressing the call for better practices, the current study draws upon the use of action songs and TPR as a method to develop early literacy in young learners.

- Tamil Vernacular Primary School Types and Low Enrolment Schools

In Malaysia, public primary school education is divided based on the medium of instruction, i.e. Malay medium National Schools (Sekolah Kebangsaan, SK) and non-Malay medium National-type Schools which are known as 'vernacular schools' (Sekolah Jenis Kebangsaan, SJK). Vernacular schools are further divided into National-type Chinese Schools (SJK Cina) with Mandarin as the medium of instruction, and National-type Tamil Schools (SJK Tamil) with Tamil as the main language of instruction. In the SK type schools, Malay Language is the medium of instruction for all content subjects and English is one of the subjects taught. On the other hand, in the SJK type schools, such as the one in the current study, Malay and English Languages are compulsory subjects while all other content subjects are taught in Tamil or Mandarin. What this means is that the students have three languages to master, and English becomes their third language.

Acquisition of English Language as their third language in Vernacular Type Schools (SJK) brings in a few obstacles for their language learning. Based on observations and discussions with students in the school, we identified some of the challenges faced by them in relation to the difference in background, complexity of language level, cross-linguistic differences between English language and their mother tongue as well as learning English as a Second Language. Generally, the students' English Language proficiency level is between low and medium, and they perceive it as a difficult subject to learn. Usage of Tamil is prohibited during the English lessons, and with the teacher's 
instructions being in English, the majority of the Tamil- speaking students struggle with understanding the instructions. This leads to them having apprehensions about learning the language. Furthermore, they have difficulties in acquiring the language because they rarely listen to and use the language. Pupils only listen to and use English Language in their classroom for three hours per week. This is definitely insufficient for them to engage with the language to develop the level of literacy required of them. It is thus, a challenge for the teachers as well as students have negative perceptions and high levels of anxiety to learning English.

In addition to the challenge of learning English as a third language after Tamil and Malay at a Tamil Vernacular Primary School, the respondents of this study can be said to have another setback which is that they belong to a Low Enrolment School (Sekolah Kurang Murid, SKM). SKM schools are those with less than 150 students in total, with some classrooms having as few as two (2) students only. For example, in the current study, the total number of students enrolled from Year 1 to 6 is thirty two (32), with two (2) English Language teachers for all the different classes. The Year 4 students, who are the respondents for this study, are seven (7) in total. Having very few students in a classroom maybe disadvantageous for the learners especially in a language learning environment that requires interaction, group involvement and opportunities for practice of language skills, but for the teachers, a smaller classroom gives the opportunity to work with varying approaches as well as to give more attention to the needs of individual learners. The current study thus, uses the advantage of having a smaller group of learners to investigate the use of action songs and Total Physical Response (TPR) as a method to facilitate developing listening skills in a fun and enjoyable way that could reduce anxiety levels and negative perceptions of learning English amongst Tamil Vernacular Primary School students.

The study aims to answer the following research questions:

i. Does the use of songs and TPR help to promote the development of listening skills among young learners?

ii. What are the perceptions of teachers about the use of songs and TPR in the teaching of listening for Year 4, low proficiency level students, at a low enrolment Tamil Vernacular Primary School?

\subsection{Second Language Listener, Songs and Total Physical Response for Listening Skills of Young Learners}

Listening is a receptive skill because the focus is on receiving information from an outside source in which it acts as a base for developing the much needed vocabulary in that language (Sevik, 2012). Listening therefore, is the ability to identify and understand what others are saying. This makes listening, an active activity. For learners, listening is how a spoken language becomes input. In this section, we discuss second language learners' and listening, followed by songs for active listening of young learners. The section ends with Total Physical Response and Actions Songs for the development of listening skills. 


\section{- Second Language Listeners}

First language learner (L1) listeners have many hours of passive listening before there is a need to attend to the messages they hear, whereas second language learner (L2) listeners are usually not so privileged (Flowerdew \& Miller, 2009). The processes we use as L2 listeners may technically be similar to those of L1 situations, but barriers to comprehension and additional processes that a L2 learner must perform can make listening in a second language a difficult task. Although this may hinder the listening process of both L1 and L2 listeners, L1 listeners would be able to manage by means of linguistic inference or by falling back on their cultural background, thus enabling them to make sense of what is being said at that time of disturbance. On the other hand, an L2 listener may need to hear the full message in order to comprehend it. Once the message is in the short term memory, the L1 listener will be able to access automatic processing devices. Consequently, these processes allow the listener to quickly encode or decode the message and decide whether it is worth keeping it in the long term memory (Millington, 2011).

The main reason for the teaching of the listening skill is that listening may be a foundation for other language skills and any help we can give students in performing that skill will help them to become better listeners and more proficient in the target language (Linse in Sevik, 2012).Thus, teachers must take into account that teaching listening helps students to acquire language subconsciously even if teachers do not draw attention to its special features (Sevik, 2012). The usual method for exposing students to spoken English (after the teacher) is through the use of taped materials which can exemplify a wide range of topics such as plays, songs with lyrics, advertisements and all manner of spoken exchanges. Thus, to help L2 learners develop their listening abilities, we need effective methods that account for not only the core factors of how listeners process information (top-down, bottom-up, interactive) but also all the other dimensions that may affect the way messages are perceived and processed (Flowerdew \& Miller, 2009). To this end in the following sections, we draw upon the literature on use of songs and TPR as to justify it is an effective method for the development of listening skills among young learners.

\section{- Songs, Active Listening and Young Learners}

As Harmer (2000) posits, music is a powerful stimulus for student engagement because it speaks directly to our emotions while allowing us to use our brains to analyze it and its effects. In a similar vein, others points out that when a first grader is listening in an ESL context, he or she is being exposed to sounds and pronunciation that he or she might never have heard before, for example the new language might have a different phonetic system to that of the students' mother tongues and therefore active listening is needed to process and memorize those unfamiliar sounds (e.g. Porvaldsdottir (2008), Krouse (1988). This requires the student to listen with an active mind and which can propel interest in the subject. Thus songs can be a useful means to achieve this. Languages are normally learnt by ear and the learners' are first exposed to the structure and vocabulary of the target language usually through listening. Like language, music is based on sounds and rhythm and so that is why songs can indirectly help pupils' engage in the language and thus enhancing pupils' listening skills. 
One of the prominent features of songs is its rhythmic and repetitive nature (Ratnasari, 2007). The repetitive nature of songs, the joy they induce to the learning activity and the associative power between the melody and the content of the word reinforce the attainment of the language to be internalized both covertly and overtly (Sevik, 2012). Songs also have become an important tool in creating a safe and natural classroom ethos, and therefore have proven to be helpful in overcoming feelings of shyness, anxiety and hesitation on the part of the learners. Songs help children to learn because they provide a safe, non-threatening context within which to play with language (Sevik, 2012). They provide excellent opportunities for repetition and practise which would otherwise be tedious. This repetition helps learning and this in turn leads to familiarity so that children feel comfortable with a language other than their mother tongue. When our ESL learners are exposed to songs, the repetition acts as drills and reinforce the development of their listening skills.

\section{- Total Physical Response (TPR)}

Asher's (1977) Total Physical Response (TPR) is based on the view that children, in learning their first language appear to do a lot of listening before they speak, and that their listening is accompanied by physical responses such as reaching, moving or looking. The motor activity is a right-brain function that should precede left-brain language processing. Asher (1977) was also convinced that language classes were often the locus of too much anxiety, so he devised a method that was as stressfree as possible, where learners would not feel overly self-conscious and defensive (Brown, 2007). Commands were an easy way to get learners to move about and to loosen up: Stand up, Sit down and so on. As cited by Sevik (2012), according to Richards and Rodgers, TPR is built around the coordination of speech and action, focusing on teaching languages through physical activity. Saricoban and Metin (2000), suggest that adding motions that parallel the words of the song makes the songs more meaningful and enjoyable. Choosing action songs to which learners can dance or act while singing will ensure a lively atmosphere. According to Chang (2009), effective active listening conditions for young learners include movement or the use of visual aids as these lead to greater levels of on-task behaviour during group listening experiences. In addition, active listening, including small hand movements in response to specified characteristics of the music during listening, achieves higher levels of attention which leads to the understanding that active listening provides more efficient listening environments for young learners Chang (2009; Sims (2002).

\section{- Songs and TPR Approach to Promote Active Listening Skills}

Porvaldsdottir (2008) states that active listening is the process whereby students start to add feelings and understand their ability to listen and check for comprehension and body language is an important aspect to focus on while listening for understanding. Songs in the classroom are often based on body language or body movements, for example "If you're happy, happy and you know it, Clap your hands". The students will have to listen and understand in order to follow the song and know what to do when the word happy is heard. According to Sevik (2012), choosing action songs to which pupils' can dance or act to while singing will ensure a lively atmosphere of active listening. This does not only provide learners with second language exposure but also promote language learning experience through 
listening skills. It is thus, our view that for Tamil Vernacular Type primary school students, who have negative perceptions and high levels of anxiety about learning English, teachers need to introduce methods that would reduce students' inhibitions and anxiety. Thus, our strategy of incorporating songs to develop pupils' listening skills rests on the basis that it can surely lower pupils' affective filter levels. Once their inhibition is reduced, they would be more receptive to learning a second language or third language and even a foreign language. Taking into consideration the multitude of benefits of the use of action songs and TPR for the development of listening skills, our study shares the findings of an intervention that used the approach in a Tamil medium, low proficiency, Year 4 classroom.

\subsection{METHODOLOGY}

This study used the within-group experimental design, an method that is used for studies with a limited number of respondents and that may not involve more than one group (Creswell, 2012). As the current study was conducted in a Low Enrolment School, with a total of seven (7) students in the Year 4 classroom, this experimental design was suitable. In addition to the experimental investigation, semi-structured interviews were conducted that involved five teachers.

\section{- Procedure}

The implementation of the study was conducted in five stages:

Stage 1: Pre-test: Pupils were given a set of pre-test which consisted of listening to a song and answering question, i.e. circle the correct answer. The scores were then tabulated before the treatment stage to measure the students' listening skill ability.

Stage 2: Treatment Procedure: Students were given the intervention during six lessons, which consisted of six 'Listen \& Do' activities. The activities included 'listen and circle', 'listen and match', 'listen and paste pictures', 'listen and number' and 'listen and rearrange'. Each lesson was conducted for an hour, with the treatment conducted one-day a week. The intervention period was for six weeks. The lessons were carried out in the classroom during school hours.

Stage 3: Post-test: After the treatment period, a post-test with similar activities as the pre-test was given to the students which included a new set of songs.

Stage 4: Interview: Five teachers were selected and interviewed with a set of six main questions, to find out their perceptions of teaching listening using songs and TPR. The interviews were then transcribed for analysis.

\section{Stage 5: Data Analysis}

The scores from the pre-test and post-test are gathered and tabulated, whereby the margin of improvement from the tests are compared to measure the improvement of all the students' after the intervention treatment period. Using SPSS 21 software, Paired T-test is used. As for the teachers' semi-structured interviews, the transcribed data is coded. 


\section{- Respondents}

For the experimental investigation, students of Year 4 (ten-year olds) were selected, with two female and five male students, Tamil is their mother tongue. They converse in Tamil in school and at home. In a Tamil vernacular type school, their only exposure to the English Language is in the classroom, for three hours a week. Even so, they only speak when it is necessary and to answer questions asked. Other than that, they would normally be silent or whisper in Tamil to their friends.

For the semi-structured interviews, five graduate English Language teachers, with three to thirty-years of teaching experience, were selected from neighboring low-enrolment Tamil Vernacular type (SJK) schools. The questions for the semi-structured interview were adapted from the questionnaire used by Sevik (2011). Six questions in total focused on the importance given to teaching listening skills, teaching of songs and incorporating TPR in teaching. The reliability of the questionnaire is 0.674 , which shows a moderate reliability.

\subsection{FINDINGS AND DISCUSSION}

The study aimed to investigate the use of action songs and Total Physical Response to develop listening skills of low proficiency, Tamil speaking young learners. In the following sections, we share the findings and discussion.

\subsection{Research Question 1: Does the Use of Songs and TPR Help to Promote the Development of} Listening Skills among Young Learners?

\section{- Pre-test and Post-test}

Table 4.1 shows a summary of the raw scores of the pre-test and post-test for the within-group experimental students who underwent treatment during lessons that used songs and the TPR method. 
Table 4.1 Summary of pre-test and post-test

\begin{tabular}{|c|c|c|c|c|}
\hline No & Students & $\begin{array}{l}\text { Pre-test } \\
\text { Scores }\end{array}$ & $\begin{array}{l}\text { Post-test } \\
\text { Scores }\end{array}$ & $\begin{array}{l}\text { Margin of Difference } \\
\text { (Post Test - Pre Test) }\end{array}$ \\
\hline 1 & S1 & 30 & 60 & 30 \\
\hline 2 & S 2 & 60 & 86 & 26 \\
\hline 3 & S 3 & 30 & 58 & 25 \\
\hline 4 & S 4 & 10 & 46 & 36 \\
\hline 5 & S 5 & 50 & 78 & 28 \\
\hline 6 & S 6 & 20 & 44 & 24 \\
\hline 7 & S 7 & 40 & 62 & 22 \\
\hline & $\Sigma$ & 240 & 354 & 191 \\
\hline & Mean & 34.29 & 50.57 & 27.29 \\
\hline & Min Score & 10 & 44 & \\
\hline & Max Score & 60 & 86 & \\
\hline
\end{tabular}

The mean score obtained for the Pre Test and Post Test are 34.29 and 50.57, respectively. The minimum score obtained for the pre-test is $10(\mathrm{~S} 4)$ and the maximum score is 60 (S2). For the posttest, the minimum score obtained is $44(\mathrm{~S} 6)$ and the maximum score is $86(\mathrm{~S} 2)$. This shows an increase of 27.29 as the margin of difference for the mean scores. On the other hand, while the treatment was conducted, the range for margin of difference is from 22 to 36 . Student 4 showed the most improvement by having an increase of 36 from a pre-test score 10 and to a post test score of 46 . Student 7 on the other hand, has increased by 22. As a whole, from the post-test, it can be seen that there are positive correlation between the students' performance and the intervention they underwent. This shows that the students are receptive to the use of songs incorporated with TPR as they show a significant improvement in their scores in the pretest.

\section{- SPSS: Paired T-test Analysis}

Statistical analysis is performed by using the SPSS Program with alpha 0.05 towards the dependent variables - the scores in the Pre Test and Post Test. The Pre Test and Post Test both contain ratio data. Therefore, it is advised to perform the parametric test in analysing the significance of these two variables. However, the first requirement of the parametric test is that the data from both variables must be normal. Thus, the normality of the mean of the Pre Test scores and the mean of the Post Test scores is tested using the Shapiro-Wilk Test. This test was run with the following hypotheses: 
a. Null hypothesis: The population is normally distributed.

b. Alternative hypothesis: The population is not normally distributed.

Table 4.2 The Shapiro-Wilk Tests of Normality for the Pre-test and Post-test

\begin{tabular}{|l|l|l|l|}
\hline & \multicolumn{3}{l|}{ Shapiro-Wilk } \\
\hline & Statistic & df & Sig. \\
\hline Pre-Test & $.980 \quad 7$ & 7 & .958 \\
Post-Test & .927 & 7 & .525 \\
\hline
\end{tabular}

Table 4.2 shows that the significance of the Pre Test and Post Test as 0.958 and 0.525 , respectively. This means that both the Pre Test and Post Test are normally distributed (when significance is greater than 0.05). For that reason, the parametric test of the paired sample t-test is used to investigate if there are significant differences between the mean of Pre-test and Post-test scores. The paired sample t-test was run with the following hypothesis:

a. Null hypothesis: There is no significant difference between the mean of Pre-test and the mean Post-test scores.

b. Alternative hypothesis: There is a significant difference between the mean of Pre-test and the mean Post-test scores.

Table 4.3 shows the descriptive statistics of the Pre-test and Post-test. There were 7 students (N). The Pre-test gave a mean score of 34.29 with a standard deviation of 17.182. The Post-test gave a mean score of 62.00 with a standard deviation of 15.449 .

Table 4.3 Paired Samples Statistics of Pre-test Score and Post-test Score

\begin{tabular}{|ll|l|l|l|l|}
\hline & & Mean & N & Std. Deviation. & Std.Error Mean \\
\hline Pair 1 & Pre-Test & 34.29 & 7 & 17.182 & 6.494 \\
& & & & & 5.839 \\
& Post-Test & 62.00 & 7 & 15.449 & \\
\hline
\end{tabular}

The mean for the Post-test is higher than that of the Pre-test. It means that the scores in the Post-test are higher than the Pre-test scores. We can conclude that as the mean of the Post-test is higher, the implementation of action songs and TPR in the teaching of the listening skills during the intervention, as treatment, shows an effective result.

Next, Table 4.4 shows that the significant score is less than 0.05 , which is 0.000 , hence it has correlation between the mean of the pre and post tests. The correlation is 0.967 ; this indicates that the 
correlation is positive and large, whereby there is less standard error in the testing hypothesis. The mean of the paired samples test shows an increase. This indicates that the Post Test has higher value compared to the pre-test. This means that there is a significant difference between the mean of Pre Test and Post Test scores. The significant value, 0.000, is lower than the value of alpha, .05, thus rejecting the null hypothesis. This means that the Pre Test scores have a significant difference from the Post Test scores $(t(d f)=-16.167(6), \mathrm{p}=0.000)$. These results suggest that there is significant improvement in the students' Post Test scores after the intervention with treatment of action songs and TPR to develop their listening skills.

Table 4.4 Paired Sample t-test

\begin{tabular}{|c|c|c|c|c|c|c|c|c|c|}
\hline & & \multicolumn{5}{|c|}{ Paired Differences } & \multirow[b]{3}{*}{$\mathrm{t}$} & \multirow[b]{3}{*}{$d f$} & \multirow{3}{*}{$\begin{array}{l}\text { Sig. } \\
\text { tailed) }\end{array}$} \\
\hline & & \multirow[b]{2}{*}{ Mean } & \multirow{2}{*}{$\begin{array}{l}\text { Std. } \\
\text { Deviation }\end{array}$} & \multirow{2}{*}{$\begin{array}{l}\text { Std. Error } \\
\text { Mean }\end{array}$} & \multicolumn{2}{|c|}{$\begin{array}{l}95 \% \text { Confidence Interval } \\
\text { of the Difference }\end{array}$} & & & \\
\hline & & & & & Lower & Upper & & & \\
\hline $\begin{array}{l}\text { Pair } \\
1\end{array}$ & $\begin{array}{l}\text { PreTestP } \\
\text { PostTest }\end{array}$ & -27.714 & 4.536 & 1.714 & -31.909 & -23.520 & -16.167 & 6 & .000 \\
\hline
\end{tabular}

4.2 Research Question 2: What are the Perceptions of Teachers about the Use of Songs and TPR in the Teaching of Listening for Year 4, Low Proficiency Level Students, at a Low Enrolment Tamil Vernacular Primary School?

\section{- Interview with Teachers}

In response to Research Question 2, semi- structured interviews comprising six questions, were conducted with 5 teachers who teach in low enrolment (SKM) Tamil Vernacular National Type Schools (SJK) to find out the English Language teachers' perceptions about the use of songs and the incorporation of TPR in the teaching of listening in national - type School. All five teachers are qualified degree holders with at least three years of The responses of the teachers based on the questions are discussed below.

\section{- Importance of Teaching Listening Skill}

All of the teachers agreed that listening plays an important role in the language learning process. The teachers referred to the KSSR syllabus to point out the importance of it listening skills. They generally believe listening skills would improve students' pronunciation and enable them to comprehend the message well, thus giving them greater focus on learning of the language. The teachers also stated that they have been exposing listening skill tasks and activities to their students and allocate between 15 to 30 minutes for the lessons. This shows that the teachers are aware of the benefits of teaching listening skill. This is similar to the findings of Sevik (2015) that teachers are 
aware of the importance of teaching listening skill. However, based on the KSSR Standard Document, teachers are required to spend 60 minutes for listening skills. We can conclude that although the teachers are aware of the benefits of listening skills for language learning, their allocation of time is insufficient. It is obvious, that they give more importance to the other skills in comparison to listening.

\section{- Teaching Listening Skill and Using Action Songs and TPR in the Classroom}

Teachers stated that they use a variety of activities during their listening lessons, such as stories, songs, jazz chants, games, as well as text-based and audio based activities. The selection of songs for their lessons is based on the topic that is taught, or words used for the lesson, to introduce rhymes and children song, learners' age group, and content of the lesson as well as the students' interest. This shows that the teachers try different methods to teach listening. However, only two out of five teachers said they use songs whereas the other three teachers use games and task based listening activities. Hence, they do not use songs very often in their listening lessons. However, all five teachers stated that they have used songs in their lessons and are aware of the benefits of teaching using songs, for example they talked about the features in songs such as melody and rhythm which capture students' interest and can increase their attention span and aid vocabulary acquisition. They agreed that using songs can enhance the listening skills of the students. Three out of the five teachers used songs as an activity for pre-listening, whereas only two used songs for while-listening activity. Only one of the teacher mentioned choosing songs that are fun and also songs that have actions. For example, the teachers talked about incorporating movements to songs, and how it helps students to remember the song better. Here, it can be concluded that teachers are using songs to teach listening skills but they are not tapping into the full potential of using action songs for language learning. Teachers' responses from the interview showed that most of the teachers use different methods in teaching listening skills. This is similar to Tse's (2015) findings on the perspectives of Malaysian ESL teachers on the efficacy of songs in the classroom, which showed that the teachers have a positive impression of the effectiveness of songs.

Our findings also show that novice teachers seemed to be more engaged in teaching listening skills and give more focus due to the reason that they have been exposed to the new format of the KSSR during their training period. Since there are continuously many changes to KSSR, senior teachers may not be up to date with their knowledge of KSSR, with grammar and exam format being their focus while teaching, this is especially so, when pupils move to Years 4, 5 and 6. Although songs prove to be a most interesting method for teaching English (Tse (2015), our study shows that teachers do not have enough exposure to the benefits of action songs and TPR especially for developing listening skills. 


\subsection{CONCLUSIONS}

The quantitative findings showed a positive result that respondents from the within group intervention showed a significant improvement with the usage of songs and TPR to enhance listening skills. The findings also showed that usage of songs and TPR simultaneously showed a vast improvement in their listening skill as well as their comprehension as well. From the qualitative findings, we conclude that lack of time and teachers' lack of knowledge of the true benefits of action songs/TPR are the real barriers. Even though, many efforts are being executed by the teachers to enhance students' acquisition of the target language, for vernacular-type schools as there are only six periods per week although the students have to master three languages and English becomes their third language learnt in school, teachers should teaching songs incorporating with TPR as this method can enhance learners' listening skills as shown in our study. This is so especially for students from Vernacular Type Schools as English Language is a third language to learn, after their mother tongue and Malay Language and students have more apprehensions towards English Language. As Low Enrolment Schools are usually cut away from the cities and located in areas where the students have less exposure and opportunities to speak in English, the learners' have high levels of anxiety and inhibitions. Thus, it is up to the teachers to make learning English fun enjoyable yet effective. Using songs and TPR in teaching listening skill is a sure way to achieve this. Teachers have the responsibility to make the lessons more meaningful and effective as well as to cater to students' needs and their acquisition level.

We conclude that it is important for teachers to understand the reasons of using action songs to teach listening (Sevik, 2012) as action songs can aid learners from Low Enrolment Vernacular Type schools to develop their listening skills and pronunciation, but the utmost benefit of using songs in lessons, is that they are highly entertaining (Millington, 2011) and can alleviate language learning apprehensions and inhibitions. We would like to add that teachers tend to overlook the importance of listening skills as a whole since it is not assessed in public examinations. It is only emphasized in Form Six for the Malaysian University English Test (MUET), which is a test of English Language proficiency for university admissions. Even for school based assessment, there is oral examination involved as offline documentation, yet, its effectiveness and application need to be looked into.

\section{REFERENCES}

Alderson, C., Brunfaut, T., \& Harding, L. 2015. Diagnostic Assessment of Reading and Listening in a Second or Foreign Language: Elaborating on Diagnostic Principles. Language Testing. 317-336. Alisaari, J. 2016. Songs and Poem in the Second Language Classroom. The Hidden Potential of Singing for Developing Writing Fluency.Thesis. University of Turku.

Creswell, J. W. 2012. Educational Research: Planning, Conducting, and Evaluating Quantitative and Qualitative Research. Boston: Pearson.

Diakou, M. 2013. Using Songs to Enhance Language Learning and Skills in the Cypriot Primary EFL Classroom. Thesis. The Open University. 
Dokumen Standard Kurikulum Sekolah Rendah Bahasa Inggeris SK Bahagian Pembangunan Kurikulum. 2011. Putrajaya: Kementerian Pendidikan Malaysia.

Kirsch, C. 2006. English Primary Children Learning Foreign Languages at Home and at School: A Sociocultural Approach to the Development of Language Learning Strategies. Doctoral Dissertation. Goldsmiths College (University of London).

Klein, K. 2005. Teaching Young Learners. English Teaching Forum. 43(1): 12-17.

Millington, N. T. 2011. Using Songs Effectively to Teach English to Young Learners. Language Education in Asia. 131-141.

Normardhiah Ibrahim. 2018. A Case on Tamil Education in Malaysia: Is Tamil Education Being Sidelined? WHS Web of Conferences 53, 03006 https://doi.org/10.1051/shsconf/20185303006 ICHSS 2018.

Ratnasari, H. 2007. Songs to Improve the Students' Achievement in Pronouncing English Words. . Languages and Arts Faculty Semarang State University.

Reily, V., \& Ward, S. M. 1997. Very Young Learners(Resource Books for Teachers). Oxford: Oxford University Press.

Sarcoban, A. \& E. Metin. 2000. The Internet TESL Journal. 10. http://itesjl.org/.

Selvarah, K. \& Zaidahtol Akmaliah Lope Pihie. 2015. The Relationship between School Culture and School Innovativeness among National Type Tamil Primary Schools, SJK(T)S in Kuala Langat District, Selangor. International Journal of Humanities Social Sciences and Education (IJHSSE). 2/1: 126-137.

Şevik, M. 2012. First Step to Effective Listening: "Listen and Show" Songs. International Journal of English and Education. 1(1): 9-18.

Şevik, M. 2011. Teacher Views About Using Songs in Teaching English to Young Learners. Educational Research and Reviews. 6(21): 1027-1035.

Sevik, M. 2012. Teaching Listening Skills to Young Learners through "Listen and Do" Songs. English Teaching Forum. 3: 1-17.

Sigurðardóttir, D. 2012. Language Learning Through Music. TKT, Teaching Knowledge Test. Young Learners ( $Y L$ ).

Tse, A. Y. 2015. Malaysian Teachers' Perspectives on Using Songs in English Language Teaching. International Journal of Social Science and Humanity. 5/1: 87-89.

Young, D. J. 1992. Language Anxiety from the Foreign Language Specialist's Perspective: Interviews with Krashen, Ommaggio Hadley, Terrell, and Rardin. Foreign Language Annals. 25(2): 157172. 